\title{
Diaphragma Sellae Meningioma
}

National Cancer Institute

\section{Source}

National Cancer Institute. Diaphragma Sellae Meningioma. NCI Thesaurus. Code C5283.

A mening ioma that arises from the diaphragma sellae. 